\title{
Silica Supported Tungstosilicic Acid as an Efficient and Reusable Catalyst for the One-Pot Synthesis of $\beta$-Acetamido Ketones via a Four-Component Condensation Reaction
}

\author{
Masoud Nasr-Esfahani, ${ }^{*}$ Morteza Montazerozohori, and Tahere Gholampour \\ Department of Chemistry, Yasouj University, Yasouj 75918-74831,Iran.*E-mail: manas@mail.yu.ac.ir \\ Received August 19, 2010, Accepted October 7, 2010
}

\begin{abstract}
Silica supported tungstosilicic acid has been used as an effective catalyst for a modified Dakin-West one-pot, fourcomponent condensation of an aryl aldehyde, an aryl ketone, acetyl chloride and acetonitrile for the synthesis of $\beta$-acetamido ketones. This catalytic system can act as an active, inexpensive, recoverable and recyclable catalyst. Some advantages of this system are short reaction times, good to excellent yields, easy work up and the ability to be carried out at the large scale reactions.
\end{abstract}

Key Words: $\beta$-Acetamido ketone, Silica supported tungstosilicic acid, Four-component, Dakin-West reaction

\section{Introduction}

Heteropoly acids (HPAs) are a unique class of active materials in both redox and acid catalysis, ${ }^{1-3}$ which are widely used as catalysts in various reactions. HPAs with Keggin structure are the most studied class within polyoxometalates, because they possess relatively high thermal stability ${ }^{4}$ and acidity, ${ }^{5}$ and, 12-tungstophosphoric acid and 12-tungstosilicic acid are the usual catalysts of choice because of their high acidic strength, relatively high thermal stability, and lower oxidation potential. HPAs can be used either directly as a bulk material or in supported form in both homogeneous and heterogeneous systems. They are highly soluble in polar solvents but insoluble in non-polar ones. Some advantages of HPAs are non-corrosive, environmentally friendly because of its reusability, economically feasible solid acid catalysts compared to conventional homogeneous acids, high flexibility, in modification of the acid strength, ease of handling, non-toxicity and experimental simplicity. ${ }^{6}$ From the synthetic point of view, a variety of useful transformations such as oxidation of alcohols, ${ }^{7}$ Friedel-Crafts ${ }^{8}$ and Mannich reactions, ${ }^{9}$ cyanosilylation, ${ }^{10}$ ring-opening of epoxides, ${ }^{11}$ and dehydration, ${ }^{12}$ have been developed using HPAs as catalysts. Increasing of the surface area or even better, increasing of the number of accessible acid sites of the HPAs is important. This can be achieved by dispersing the HPAs on solid supports with high surface area. ${ }^{13-15}$ These supported catalysts have been widely studied and found useful in many reactions such as the synthesis of 2,4-dihydropyrimidones, ${ }^{16}$ metanethole, ${ }^{17} \alpha$-aminonitriles $^{18}$ and esterification. ${ }^{19,20}$

The $\beta$-acetamido carbonyl compounds, in that their skeletons exist in a number of valuable biologically or pharmacologically active compounds, ${ }^{21,22}$ has gained considerable attention in organic synthesis, owing to their importance as versatile intermediates for preparation of $\beta$-amino acids, ${ }^{23}$ or 1,3 -amino alcohols $^{24}$ as well as for the synthesis of various antibiotics such as nikkomycins or neopolyoxines ${ }^{25}$ and potent molecules in $\alpha$-glucosidase inhibitory activity. ${ }^{26}$

$\beta$-Acetamido ketones were usually prepared through Michael addition to $\alpha, \beta$-unsaturated ketones, ${ }^{27}$ acylation of $\beta$-amino- ketones, ${ }^{28}$ or photoisomerisation of phthalimides. ${ }^{29}$

The Dakin-West reaction is the conventional way for the synthesis of $\beta$-acetamido ketones, involving condensation of an $\alpha$-aminoacid with acetic anhydride in the presence of a base via an intermediate azalactone. ${ }^{30}$ Iqbal and coworkers reported the best known route for the synthesis of $\beta$-acetamido carbonyl compounds in the one-pot condensation of an aldehyde, an enolizable ketone, acetyl chloride, and acetonitrile catalyzed both $\mathrm{CoCl}_{2}{ }^{31}$ and Montmorillonite K-10 clay. ${ }^{32} \mathrm{~A}$ few catalysts have already been applied for the synthesis of $\beta$-acetamido ketones using this method, including $\mathrm{Sn}(\mathrm{II}){ }^{33} \mathrm{Sc}$ (III) triflates, ${ }^{34}$ $\mathrm{InCl}_{3},{ }^{34} \mathrm{H}_{2} \mathrm{SO}_{4} / \mathrm{SiO}_{2},{ }^{35}$ Zirconia, ${ }^{36} \mathrm{ZnO},{ }^{37}$ phosphotungstic acid, ${ }^{38}$ sulfamic acid, ${ }^{39 \mathrm{a}}$ aluminium hydrogen sulfate, ${ }^{39 \mathrm{~b}} \mathrm{CeCl}_{3},{ }^{40}$ cerium(IV) sulfate, ${ }^{41}$ and Nafion- $\mathrm{H}^{42}$ The role of these acidic catalysts is activation of the carbonyl group of the aldehyde toward the addition of acetonitrile $\mathrm{A}^{43,44}$ or toward the attack of the enole of aryl ketone. ${ }^{45}$ These methods are valuable but they suffer from different drawbacks such as hazardous reagents, high temperature, expensive catalysts, long reaction time, tedious workup and low yield. Hence, the development of a simple and new protocol with more efficiency is still in demand.

Multicomponent reactions (MCRs) have proved to be remarkably successful in generating highly complex structures in a single synthetic step operation. ${ }^{46}$ This process has emerged as an efficient and powerful tool in modern synthetic chemistry allowing the facile creation of several new bonds in a one-pot transformation. The organic chemists have transformed this powerful technology into one of the most efficient and economic tools for parallel and combinatorial synthesis. ${ }^{47}$ One eminent MCR that produces an interesting class of compounds is the Dakin-West reaction, which is a powerful synthetic method for the preparation of $\beta$-acetamido carbonyl compounds.

It is, therefore, interesting to find out the behavior of a new catalytic system in the synthesis of $\beta$-acetamido ketones in a one-pot multicomponent way.

\section{Experimental}

Chemicals were purchased from Merck, Fluka and Aldrich 
chemical companies. All of the products were identified by comparison of their physical and spectral data with those of authentic samples. IR spectra were recorded on a JASCO-FTIR680 spectrophotometer. ${ }^{1} \mathrm{H}$ NMR spectra were obtained with a Bruker 400 Ultrasheild (400 MHz) spectrometer.

Preparation of the supported catalyst. The silica gel supported $\mathrm{H}_{4} \mathrm{SiW}_{12} \mathrm{O}_{40}$ was prepared by mixing silica gel $(1.4 \mathrm{~g}$, Merck grade $40,0.063-0.2 \mathrm{~mm})$ with a solution of acid $(0.60 \mathrm{~g})$ in distilled water $(20 \mathrm{~mL})$. The resulting mixture was stirred for $30 \mathrm{~min}$. After removal of water in a rotary evaporator, the solid powder was dried at $80{ }^{\circ} \mathrm{C}$ for $4 \mathrm{~h}$ followed by $4 \mathrm{~h}$ calcinations at $170{ }^{\circ} \mathrm{C}$.

General procedure for the preparation of $\beta$-acetamido ketones. A mixture of the aryl aldehyde $(1 \mathrm{mmol})$, aryl ketone $(1 \mathrm{mmol})$, acetyl chloride $(0.3 \mathrm{~mL})$ and acetonitrile $(2 \mathrm{~mL})$ in the presence of $\mathrm{H}_{4} \mathrm{SiW}_{12} \mathrm{O}_{40}-\mathrm{SiO}_{2}\left(0.1 \mathrm{~g}\right.$, equal to $\left.0.04 \mathrm{mmol} \mathrm{H}^{+}\right)$ was heated at $80{ }^{\circ} \mathrm{C}$, with stirring for $20-60 \mathrm{~min}$. The progress of the reaction was monitored by TLC. After completion of the reaction, the mixture was filtered and the filtrate was poured into $50 \mathrm{~mL}$ ice-water. The solid product was filtered, washed with ice-water and recrystallized from ethyl acetate $/ n$-heptane to give the pure products in $75-92 \%$ yields based on the starting aldehyde (Table 3). Spectroscopic data of new compounds:

$\mathrm{N}$-[3-(4-Nitrophenyl)-1-(2,6-dichlorophenyl)-3-oxopropyl] acetamide (Table 3, entry 25): $\mathrm{mp} 78-81{ }^{\circ} \mathrm{C} ; R_{f}=0.43$ ( $n$-hexane: ethyl acetate $=1: 4)$; IR $\left[(\mathrm{KBr}) \mathrm{cm}^{-1}\right]: 3406,3105,1689$, $1674,1605,1520,1428,1400,1324,1150,1008,856,740,670$, $618 ;{ }^{1} \mathrm{HNMR}\left(400 \mathrm{MHz}, \mathrm{CDCl}_{3}\right) \delta 2.00(\mathrm{~s}, 3 \mathrm{H}), 3.70(\mathrm{dd}, J=8.0$ and $J=16.8 \mathrm{~Hz}, 1 \mathrm{H}), 3.76(\mathrm{dd}, J=8.2$ and $J=16.4 \mathrm{~Hz}, 1 \mathrm{H})$, $6.56(\mathrm{~m}, 1 \mathrm{H}), 7.18-7.36(\mathrm{~m}, 3 \mathrm{H}), 8.15(\mathrm{~d}, J=8.0 \mathrm{~Hz}, 2 \mathrm{H}), 8.33$ $(\mathrm{d}, J=7.6 \mathrm{~Hz}, 2 \mathrm{H}) ;{ }^{13} \mathrm{C} \mathrm{NMR}\left(\mathrm{CDCl}_{3}\right), \delta 23.42,42.95,48.08$, $128.73,129.67,129.45,129.87,130.26,132.65,134.07,135.42$, 139.43, 170.45, 198.23. Anal. Calcd. for $\mathrm{C}_{17} \mathrm{H}_{14} \mathrm{Cl}_{2} \mathrm{~N}_{2} \mathrm{O}_{4}$ : C, 53.56; H, 3.70; N, 7.35; Found: C, 53.4; H, 3.7; N, 7.2.

$\mathrm{N}$-[3-(4-Methoxyphenyl)-1-(2-nitrophenyl)-3-oxopropyl] acetamide (Table 3, entry 26): $\mathrm{mp} 170-172{ }^{\circ} \mathrm{C} ; R_{f}=0.45$ ( $n$-hexane:ethyl acetate $=1: 4) ; \operatorname{IR}\left[(\mathrm{KBr}) \mathrm{cm}^{-1}\right]: 3290,3080$, $1675,1648,1587,1520,1448,1250,985,820,675,598 ;{ }^{1} \mathrm{H}$ NMR (400 MHz, $\left.\mathrm{CDCl}_{3}\right) \delta 2.01(\mathrm{~s}, 3 \mathrm{H}), 3.59(\mathrm{dd}, J=7.8$ and $15.2 \mathrm{~Hz}, 1 \mathrm{H}), 3.61(\mathrm{dd}, J=7.2$ and $15.4 \mathrm{~Hz}, 1 \mathrm{H}), 5.93(\mathrm{~m}, 1 \mathrm{H})$, $6.93(\mathrm{~d}, J=8.0 \mathrm{~Hz}, 2 \mathrm{H}), 7.17(\mathrm{~d}, J=6.2 \mathrm{~Hz}, 1 \mathrm{H}), 7.40$ (t, $J=7.6$ $\mathrm{Hz}, 1 \mathrm{H}), 7.58(\mathrm{t}, J=7.8 \mathrm{~Hz}, 1 \mathrm{H}), 7.70(\mathrm{~d}, J=8.0 \mathrm{~Hz}, 1 \mathrm{H}), 7.94(\mathrm{t}$, $J=7.2 \mathrm{~Hz}, 2 \mathrm{H}) ;{ }^{13} \mathrm{C} \mathrm{NMR}\left(\mathrm{CDCl}_{3}\right), \delta 23.25,41.70,47.57,55.54$, $113.98,124.97,128.23,129.60,129.87,130.72,132.22,133.45$, 135.50, 138.31, 169.89, 198.58. Anal. Calcd. for $\mathrm{C}_{18} \mathrm{H}_{18} \mathrm{~N}_{2} \mathrm{O}_{5}$ : C, 63.15; H, 5.30; N, 8.18; Found: C, 63.0; H, 5.2; N, 8.1.

$\mathrm{N}$-[3-(4-Methoxyphenyl)-1-(2,4-dichlorophenyl)-3-oxopropyl]acetamide (Table 3, entry 27): $\mathrm{mp} 188-190{ }^{\circ} \mathrm{C} ; R_{f}=0.55$ ( $n$-hexane:ethyl acetate $=1: 4)$; IR $\left[(\mathrm{KBr}) \mathrm{cm}^{-1}\right]: 3298,3089$, $1672,1645,1592,1550,1405,1280,1256,1150,990,820,668$, 592; ${ }^{1} \mathrm{H}$ NMR $\left(400 \mathrm{MHz}, \mathrm{CDCl}_{3}\right) \delta 2.06(\mathrm{~s}, 3 \mathrm{H}), 3.37$ (dd, $J=$ 5.6 and $16.4 \mathrm{~Hz}, 1 \mathrm{H}), 3.69(\mathrm{dd}, J=5.6$ and $16.8 \mathrm{~Hz}, 1 \mathrm{H}), 3.88$ $(\mathrm{s}, 3 \mathrm{H}), 5.74(\mathrm{~m}, 1 \mathrm{H}), 6.92(\mathrm{~d}, J=8.0 \mathrm{~Hz}, 1 \mathrm{H}), 7.11(\mathrm{~d}, J=7.2$, $1 \mathrm{H}), 7.20(\mathrm{~d}, J=8.0 \mathrm{~Hz}, 1 \mathrm{H}), 7.40(\mathrm{~m}, J=8.2 \mathrm{~Hz}, 2 \mathrm{H}), 7.88(\mathrm{~d}$, $J=7.6 \mathrm{~Hz}, 2 \mathrm{H}) ;{ }^{13} \mathrm{C} \mathrm{NMR}\left(\mathrm{CDCl}_{3}\right), \delta 23.16,26.97,42.39,46.94$, $114.38,123.87,123.96,126.56,126.58,129.31,129.33,129.60$, 138.42, 146.23, 175.62, 198.87. Anal. Calcd. for $\mathrm{C}_{18} \mathrm{H}_{17} \mathrm{Cl}_{2} \mathrm{NO}_{3}$ : C, 59.03; H, 4.68; N, 3.82; Found: C, 58.9; H, 4.6; N, 3.9.
N-[3-(3-Nitrophenyl)-1-(4-nitrophenyl)-3-oxopropyl]acetamide (Table 3, entry 28): $\mathrm{mp} 157-159^{\circ} \mathrm{C} ; R_{f}=0.49$ ( $n$-hexane: ethyl acetate $=1: 4)$; IR $\left[(\mathrm{KBr}) \mathrm{cm}^{-1}\right]$ : 3300, 3090, 1692, 1642, 1607, 1424, 1325, 1125,1105, 670,593; ${ }^{1} \mathrm{H} \mathrm{NMR} \mathrm{(400} \mathrm{MHz,}$ $\left.\mathrm{CDCl}_{3}\right) \delta 1.89(\mathrm{~s}, 3 \mathrm{H}), 3.41(\mathrm{dd}, J=6.5$ and $J=17.5 \mathrm{~Hz}, 1 \mathrm{H})$, $3.72(\mathrm{dd}, J=6.5$ and $J=18.0 \mathrm{~Hz}, 1 \mathrm{H}), 5.55(\mathrm{~m}, 1 \mathrm{H}), 7.50(\mathrm{~d}$, $J=8.5 \mathrm{~Hz}, 1 \mathrm{H}), 7.59$ (dd, $J=9.0 \mathrm{~Hz}, J=16.5 \mathrm{~Hz}, 2 \mathrm{H}), 8.07$ $(\mathrm{d}, J=8.4 \mathrm{~Hz}, 1 \mathrm{H}), 8.17(\mathrm{~m}, 1 \mathrm{H}), 8.31(\mathrm{dd}, J=8.5 \mathrm{~Hz}, J=17$ $\mathrm{Hz}, 2 \mathrm{H}), 8.65(\mathrm{~d}, J=9.0 \mathrm{~Hz}, 1 \mathrm{H}) ;{ }^{13} \mathrm{C} \mathrm{NMR}\left(\mathrm{CDCl}_{3}\right), \delta 23.15$, 42.34, 49.06, 122.93, 128.72, 132.81, 134.85, 135.92, 137.44, 146.86, 148.72, 149.41, 151.78, 169.45, 198.75. Anal. Calcd. for $\mathrm{C}_{17} \mathrm{H}_{15} \mathrm{~N}_{3} \mathrm{O}_{6}$ : C, 57.14; H, 4.23; N, 11.76; Found: C, 57.0; $\mathrm{H}, 4.1 ; \mathrm{N}, 11.8$.

\section{Results and Discussion}

In continuation of our ongoing research program on tungstosilicic acid, ${ }^{48}$ we wish to report a convenient and efficient procedure for the synthesis of $\beta$-acetamido ketones in the presence of catalytic amounts of tungstosilicic acid supported on $\mathrm{SiO}_{2}$ (Scheme 1).

Preparation of the silica supported 12-tungstosilicic acid. The supported tungstosilicic acid catalyst were prepared by the method of incipient wetness. In a typical procedure, a $600 \mathrm{mg}$ portion of acid was dissolved in deionized water $(50 \mathrm{~mL})$ and impregnated drop-wise onto $1400 \mathrm{mg}$ supports under constant agitation. The resulting pastes were dried at $80{ }^{\circ} \mathrm{C}$ for $4 \mathrm{~h}$ and then calcined at $170{ }^{\circ} \mathrm{C}$ for $4 \mathrm{~h} .{ }^{49}$

FT-IR spectra can be used as a powerful technique for the investigation of surface interaction between tungstosilicic acid and inorganic support. Pure acid compound display infrared bands at $980(\mathrm{~W}=\mathrm{O}), 925(\mathrm{Si}-\mathrm{O}), 880\left(\mathrm{~W}-\mathrm{O}_{\mathrm{d}}-\mathrm{W}\right)$ and $781 \mathrm{~cm}^{-1}$ $\left(\mathrm{W}-\mathrm{O}_{\mathrm{b}}-\mathrm{W}\right){ }^{50}$ In addition, a broad, intense band centered around $3450 \mathrm{~cm}^{-1}$ (vO-H stretching) and a weak absorption at $1640 \mathrm{~cm}^{-1}$ $\left(\delta \mathrm{H}_{2} \mathrm{O}\right.$ bending) indicate the presence of water.

However, small shifts of $v \mathrm{~W}=\mathrm{O}_{\mathrm{d}}\left(973 \mathrm{~cm}^{-1}\right)$ and $v \mathrm{~W}-\mathrm{O}_{\mathrm{c}}-\mathrm{W}$ $\left(790 \mathrm{~cm}^{-1}\right)$ vibrations were registered indicating interactions of the support with the most external atoms $\mathrm{O}_{\mathrm{d}}$ and $\mathrm{O}_{\mathrm{c}}$ of the Keggin anion. Such effects are decreased with the increasing coverage.

Effect of tungstosilicic acid loading on $\mathrm{SiO}_{2}$. For investigation of the effect of different amounts of $\mathrm{H}_{4} \mathrm{SiW}_{12} \mathrm{O}_{40}$ loading on

$$
\mathrm{RCHO}+\mathrm{R}^{\prime} \mathrm{COCH}_{3}+\mathrm{CH}_{3} \mathrm{COCl} \frac{\mathrm{H}_{4} \mathrm{SiW}_{12} \mathrm{O}_{40} / \mathrm{SiO}_{2}}{\mathrm{CH}_{3} \mathrm{CN}, 80^{\circ} \mathrm{C}}
$$

\section{Scheme 1}

Table 1. Effect of $\mathrm{H}_{4} \mathrm{SiW}_{12} \mathrm{O}_{40}-\mathrm{SiO}_{2}$ weight ratios in the synthesis of $N$-(1,3-diphenyl-3-oxopropyl) acetamide from benzaldehyde and acetophenone

\begin{tabular}{cccc}
\hline Entry & $\mathrm{H}_{4} \mathrm{SiW}_{12} \mathrm{O}_{40}-\mathrm{SiO}_{2}(\mathrm{wt} \%)$ & Time $(\mathrm{min})$ & ${\text { Yields }(\%)^{a}}^{a}$ \\
\hline 1 & 10 & 80 & 60 \\
2 & 20 & 35 & 82 \\
3 & 30 & 20 & 90 \\
4 & 40 & 15 & 92 \\
\hline
\end{tabular}

${ }^{a}$ Isolated yields 
Table 2. Investigation of catalyst amount effect in the synthesis of $N$-(1,3-diphenyl-3-oxopropyl) acetamide from benzaldehyde and acetophenone $^{a}$

\begin{tabular}{ccccc}
\hline Entry & $\begin{array}{c}\text { Amount of } \\
\text { catalyst }(\mathrm{g})\end{array}$ & $\begin{array}{c}\text { Supported } \\
\text { tungstosilicic acid } \\
(\mathrm{mol} \%)\end{array}$ & $\begin{array}{c}\text { Time } \\
(\mathrm{min})\end{array}$ & $\begin{array}{c}\text { Yields } \\
(\%)^{b}\end{array}$ \\
\hline 1 & 0.025 & 0.26 & 85 & 50 \\
2 & 0.05 & 0.52 & 60 & 78 \\
3 & 0.075 & 0.78 & 35 & 85 \\
4 & 0.1 & 1.04 & 20 & 90 \\
5 & 0.125 & 1.3 & 20 & 92 \\
\hline
\end{tabular}

${ }_{30}{ }_{30} \mathrm{H}_{4} \mathrm{SiW}_{12} \mathrm{O}_{40}-\mathrm{SiO}_{2}$ was used as catalyst. ${ }^{b}$ Isolated yields.

support in the synthesis of $\beta$-acetamido ketones, various weight percents of acid were used. Table 1 shows differences in catalytic activity among catalysts having $10-40 \mathrm{wt} \%$ of $\mathrm{H}_{4} \mathrm{SiW}_{12} \mathrm{O}_{40}$ on silica. Lowering the loading of the deposited tungstosilicic acid causes the reduction of the catalytic activity. No improvement in the reaction rates and yields was observed by increasing the amount of acid on $\mathrm{SiO}_{2}$ from 30 to $40 \mathrm{wt} \%$. Since $30 \mathrm{wt} \%$ of $\mathrm{H}_{4} \mathrm{SiW}_{12} \mathrm{O}_{40}-\mathrm{SiO}_{2}$ was the best catalyst loading, it was used to study the effect of various parameters on yields.

Effect of catalyst concentration. The catalyst concentration was varied over a range of $0.025-0.125 \mathrm{~g}(0.26-1.3 \mathrm{~mol} \%$ of supported tungstosilicic acid) on the basis of the total volume of the reaction mixture. Table 2 shows the effect of catalyst concentration on the reaction of benzaldehyde and acetophenone. The yield of the corresponding $\beta$-acetamido ketones increased with increasing of catalyst concentration from 0.26 to $1.04 \mathrm{~mol} \%$. Further addition of catalyst had no noticeable effect on the yield. This was due to the fact that beyond a certain concentration, there exist an excess of catalyst sites over what is actually required by the reactant molecules, and hence, the additional catalyst does not increase the rate of the reaction. Therefore, in all further reactions $1.04 \mathrm{~mol} \%$ was used for $30 \mathrm{wt} \%$ of $\mathrm{H}_{4} \mathrm{SiW}_{12} \mathrm{O}_{40}-\mathrm{SiO}_{2}$.

Synthesis of $\beta$-acetamido ketones catalyzed by supported tungstosilicic acid. The results from the reactions of aryl aldehydes, aryl methyl ketones and acetyl chloride in the presence of optimized $\mathrm{H}_{4} \mathrm{SiW}_{12} \mathrm{O}_{40}-\mathrm{SiO}_{2}$ in acetonitrile at $80{ }^{\circ} \mathrm{C}$ are shown in Table 3. The experimental procedure for this reaction requires no inert atmosphere. Both aromatic aldehydes and acetophenones bearing either activating or deactivating groups underwent transformation well to the corresponding $\beta$-acetamido ketones, without the formation of any side products, in high to excellent yields (Entries 1-29). All reactions were completed within $20-60 \mathrm{~min}$. It is noteworthy that no acetylation of aromatic hydroxyl groups were observed under the reaction conditions and the corresponding $\beta$-acetamido ketones were isolated in good yields (Table 3, entries 24 and 29). We observed that aliphatic aldehydes react under these conditions, but produce the corresponding product in low yields (Table 3, entry 30 ).

To use of $\mathrm{H}_{4} \mathrm{SiW}_{12} \mathrm{O}_{40}-\mathrm{SiO}_{2}$ in large scale synthesis especially in chemical laboratory, a typical reaction was performed for synthesis of 1 with tenfold amounts of reactants and catalyst with respect to one mentioned in the experimental section. The result showed the yield of $85 \%$ in this condition which is com-
Table 3. Synthesis of $\beta$-acetamido ketones in the presence of $\mathrm{H}_{4} \mathrm{Si}$ $\mathrm{W}_{12} \mathrm{O}_{40}-\mathrm{SiO}_{2}$

\begin{tabular}{|c|c|c|c|c|}
\hline Entry & $\mathrm{R}$ & $\mathrm{R}^{\prime}$ & $\begin{array}{l}\text { Time } \\
(\mathrm{min})\end{array}$ & $\begin{array}{c}\text { Yield }^{a, b} \\
(\%)\end{array}$ \\
\hline 1 & $\mathrm{C}_{6} \mathrm{H}_{5^{-}}$ & $\mathrm{C}_{6} \mathrm{H}_{5-}$ & 20 & 90 \\
\hline 2 & $3-\mathrm{NO}_{2} \mathrm{C}_{6} \mathrm{H}_{4}-$ & $\mathrm{C}_{6} \mathrm{H}_{5-}^{-}$ & 60 & 80 \\
\hline 3 & $4-\mathrm{NO}_{2} \mathrm{C}_{6} \mathrm{H}_{4}-$ & $\mathrm{C}_{6} \mathrm{H}_{5-}$ & 50 & 82 \\
\hline 4 & $2-\mathrm{NO}_{2} \mathrm{C}_{6} \mathrm{H}_{4-}$ & $\mathrm{C}_{6} \mathrm{H}_{5-}$ & 45 & 90 \\
\hline 5 & $4-\mathrm{ClC}_{6} \mathrm{H}_{4-}$ & $\mathrm{C}_{6} \mathrm{H}_{5-}$ & 30 & 90 \\
\hline 6 & 2- $\mathrm{ClC}_{6} \mathrm{H}_{4-}$ & $\mathrm{C}_{6} \mathrm{H}_{5-}$ & 25 & 90 \\
\hline 7 & 4- $\mathrm{BrC}_{6} \mathrm{H}_{4-}$ & $\mathrm{C}_{6} \mathrm{H}_{5-}^{-}$ & 25 & 90 \\
\hline 8 & $\mathrm{C}_{6} \mathrm{H}_{5^{-}}$ & $4-\mathrm{BrC}_{6} \mathrm{H}_{4-}$ & 35 & 87 \\
\hline 9 & $3-\mathrm{NO}_{2} \mathrm{C}_{6} \mathrm{H}_{4}-$ & $4-\mathrm{BrC}_{6} \mathrm{H}_{4-}$ & 40 & 87 \\
\hline 10 & $4-\mathrm{NO}_{2} \mathrm{C}_{6} \mathrm{H}_{4}^{-}$ & $4-\mathrm{BrC}_{6} \mathrm{H}_{4^{-}}$ & 45 & 86 \\
\hline 11 & $4-\mathrm{ClC}_{6} \mathrm{H}_{4-}$ & $4-\mathrm{BrC}_{6} \mathrm{H}_{4-}$ & 30 & 89 \\
\hline 12 & $2-\mathrm{ClC}_{6} \mathrm{H}_{4}-$ & $4-\mathrm{BrC}_{6} \mathrm{H}_{4-}$ & 20 & 92 \\
\hline 13 & 4- $\mathrm{BrC}_{6} \mathrm{H}_{4}-$ & 4- $\mathrm{BrC}_{6} \mathrm{H}_{4-}$ & 30 & 90 \\
\hline 14 & $2,4-\mathrm{Cl}_{2} \mathrm{C}_{6} \mathrm{H}_{3}-$ & 4- $\mathrm{BrC}_{6} \mathrm{H}_{4}-$ & 35 & 85 \\
\hline 15 & $2-\mathrm{Cl}-6-\mathrm{F}-\mathrm{C}_{6} \mathrm{H}_{3}-$ & $4-\mathrm{BrC}_{6} \mathrm{H}_{4-}$ & 50 & 83 \\
\hline 16 & $\mathrm{C}_{6} \mathrm{H}_{5-}^{-}$ & $4-\mathrm{NO}_{2} \mathrm{C}_{6} \mathrm{H}_{4-}$ & 35 & 80 \\
\hline 17 & $3-\mathrm{NO}_{2} \mathrm{C}_{6} \mathrm{H}_{4}-$ & $4-\mathrm{NO}_{2} \mathrm{C}_{6} \mathrm{H}_{4-}$ & 50 & 80 \\
\hline 18 & $4-\mathrm{NO}_{2} \mathrm{C}_{6} \mathrm{H}_{4}^{-}$ & $4-\mathrm{NO}_{2} \mathrm{C}_{6} \mathrm{H}_{4-}^{-}$ & 50 & 76 \\
\hline 19 & 4- $\mathrm{ClC}_{6} \mathrm{H}_{4-}$ & $4-\mathrm{NO}_{2} \mathrm{C}_{6} \mathrm{H}_{4-}$ & 30 & 85 \\
\hline 20 & $4-\mathrm{BrC}_{6} \mathrm{H}_{4-}$ & $4-\mathrm{NO}_{2} \mathrm{C}_{6} \mathrm{H}_{4-}$ & 40 & 92 \\
\hline 21 & $4-\mathrm{FC}_{6} \mathrm{H}_{4}-$ & $4-\mathrm{NO}_{2} \mathrm{C}_{6} \mathrm{H}_{4-}$ & 40 & 75 \\
\hline 22 & $4-\mathrm{OCH}_{3} \mathrm{C}_{6} \mathrm{H}_{4-}$ & $4-\mathrm{NO}_{2} \mathrm{C}_{6} \mathrm{H}_{4-}$ & 25 & 78 \\
\hline 23 & $4-\mathrm{CH}_{3} \mathrm{C}_{6} \mathrm{H}_{4-}$ & $4-\mathrm{NO}_{2} \mathrm{C}_{6} \mathrm{H}_{4-}$ & 40 & 75 \\
\hline 24 & $2-\mathrm{OHC}_{6} \mathrm{H}_{4-}$ & $4-\mathrm{NO}_{2} \mathrm{C}_{6} \mathrm{H}_{4-}$ & 35 & 85 \\
\hline 25 & $2,6-\mathrm{Cl}_{2} \mathrm{C}_{6} \mathrm{H}_{3}-$ & $4-\mathrm{NO}_{2} \mathrm{C}_{6} \mathrm{H}_{4-}$ & 50 & 87 \\
\hline 26 & $2-\mathrm{NO}_{2} \mathrm{C}_{6} \mathrm{H}_{4}-$ & 4- $\mathrm{CH}_{3} \mathrm{O}-$ & 40 & 84 \\
\hline 27 & $2,4-\mathrm{Cl}_{2} \mathrm{C}_{6} \mathrm{H}_{3}-$ & 4- $\mathrm{CH}_{3} \mathrm{O}-$ & 35 & 90 \\
\hline 28 & $4-\mathrm{NO}_{2} \mathrm{C}_{6} \mathrm{H}_{4-}$ & $3-\mathrm{NO}_{2} \mathrm{C}_{6} \mathrm{H}_{4-}$ & 50 & 75 \\
\hline 29 & $2-\mathrm{OHC}_{6} \mathrm{H}_{4}-$ & $3-\mathrm{NO}_{2} \mathrm{C}_{6} \mathrm{H}_{4-}$ & 30 & 80 \\
\hline 30 & $\mathrm{CH}_{3} \mathrm{CH}_{2} \mathrm{CH}_{2-}$ & $\mathrm{C}_{6} \mathrm{H}_{5^{-}}$ & 120 & 25 \\
\hline
\end{tabular}

${ }^{\mathrm{a}}$ All products were characterized by ${ }^{1} \mathrm{H}$ NMR,${ }^{13} \mathrm{C}$ NMR and IR spectroscopy and compared with those reported in the literature. ${ }^{31,41,42}$ Isolated yields.

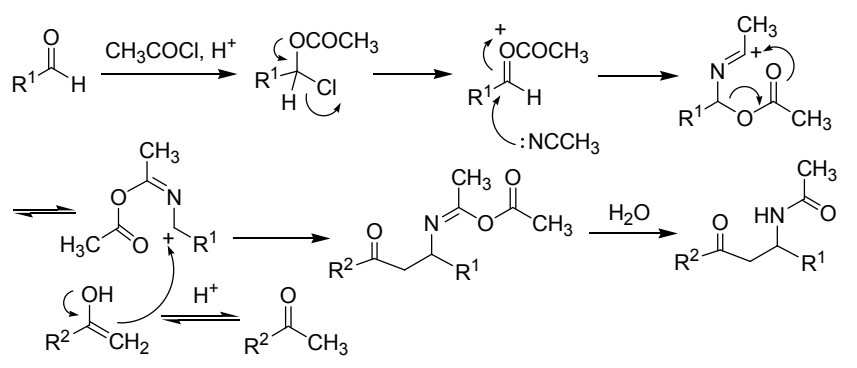

Scheme 2

parable with one in Table 3.

The plausible mechanism for the formation of $\beta$-acetamido ketones is shown in Scheme 2. The presence of acetyl chloride is necessary for the transformation and the desired product in its absence was not prepared even after $3 \mathrm{~h}$. The mechanism may involve $\alpha$-chloroacetate from aldehyde and acetyl chloride. On further reaction with acetonitrile it affords the corresponding $\alpha$-acetoxyamides which will react with the enolate form of the 
Table 4. Synthesis of some $\beta$-acetamido ketones in the presence of $\mathrm{H}_{4} \mathrm{SiW}_{12} \mathrm{O}_{40}$

Entry

${ }^{\mathrm{a}}$ Isolated yields.

ketone to afford the imidate ester and then will yield the amide.

To achieve the reaction efficiency of recovered catalyst, the reaction mixture of $\mathbf{1}$ was filtered and washed with hot acetonitrile twice to give recovered silica supported tungstosilicic acid. The recovered catalyst was used again for the synthesis of 1 that led to the yield of $84 \%$. The recovered catalyst can be reused at least four times without noticeable losing activity.

Effect of unsupported acid in synthesis of $\beta$-acetamido ketones. As shown in Table 4, in the presence of tungstosilicic acid without supporting on $\mathrm{SiO}_{2}$, the synthesis of $\beta$-acetamido ketones were performed in longer time with reduced yields in comparison with supported one. For example, in presence of $\mathrm{H}_{4} \mathrm{SiW}_{12} \mathrm{O}_{40}-\mathrm{SiO}_{2}$, the reaction of benzaldehyde and acetophenone (entry 1) was completed in $20 \mathrm{~min}$, while by using of unsupported catalyst this reaction was carried out in $100 \mathrm{~min}$ with $50 \%$ yield. This results show that supporting of tungstosilicic acid on $\mathrm{SiO}_{2}$ accelerates catalytic strength of this catalyst.

Effect of $\mathrm{SiO}_{2}$ in synthesis of $\boldsymbol{\beta}$-acetamido ketones. For investigation of the probable effect of $\mathrm{SiO}_{2}$ as catalyst in the synthesis of $\beta$-acetamido ketones, various weight percents of silicagel were used. In the synthesis of $N$-(1,3-diphenyl-3-oxopropyl) acetamide from benzaldehyde and acetophenone in the presence of $\mathrm{SiO}_{2}$, the reaction was carried out in $12 \mathrm{~h}$ in $20 \%$ yield while in the presence of $\mathrm{H}_{4} \mathrm{SiW}_{12} \mathrm{O}_{40}-\mathrm{SiO}_{2}$, the reaction of benzaldehyde and acetophenone was completed in $20 \mathrm{~min}$ and by using of unsupported catalyst, this reaction was carried out in 100 min with 55\% yield (Table 4). These results show that both supported and unsupported $\mathrm{H}_{4} \mathrm{SiW}_{12} \mathrm{O}_{40}$ accelerate rate of reaction versus $\mathrm{SiO}_{2}$ alone.

\section{Conclusion}

We have reported an efficient, inexpensive and straightforward procedure for one-pot synthesis of $\beta$-acetamido ketones using $\mathrm{H}_{4} \mathrm{SiW}_{12} \mathrm{O}_{40}-\mathrm{SiO}_{2}$ as catalyst. The catalyst can be easily prepared and can be handled safely. Moreover, non-hygroscopic and inexpensive characteristics for this transformation are other advantages of this procedure. The simple experimental procedure combined with the easy workup and good to excellent yields of products are salient features of the presented method.

Acknowledgments. We are thankful to Yasouj University for partial support of this work.

\section{References}

1. Pope, M. T. In Heteropoly and Isopoly Oxometalates; SpringerVerlag: Berlin, 1983.

2. Okuhara, T.; Mizuno, N.; Misono, M. Adv. Catal. 1996, 41, 113.

3. Hill, C. L. Chem. Rev. 1998, 98, 1.

4. (a) Drago, R. S.; Dias, J. A.; Maier, T. O. J. Am. Chem. Soc. 1997, 119, 7702. (b) Dias, J. A.; Dias, S. C. L.; Kob, N. E. J. Chem. Soc., Dalton Trans. 2001, 3, 228.

5. Dias, J. A.; Osegovic, J. P.; Drago, R. S. J. Catal. 1999, $183,83$.

6. (a) Kozhhevnikov, I.V. In Catalysis for Fine Chemical Synthesis, Catalysis by Polyoxometalates 2; Derouane, E., Ed.; Wiley: New York, 2002. (b) Romanelli, G. P.; Bennardi, D.; Ruiz, D. M.; Baronetti, G.; Thomas, H. J.; Autino, J. C. Tetrahedron Lett. 2004, 45, 8935.

7. Firouzabadi, H.; Iranpoor, N.; Amani, K. Synthesis 2003, 408.

8. (a) Kaur, J.; Griffin, K.; Harrison, B.; Kozhevnikov, I. V. J. Catal. 2002, 208, 448. (b) Lan, K.; Fen, S.; Shan, Z.-X. Aust. J. Chem. 2007, 60, 80 .

9. (a) Azizi, N.; Torkiyan, L.; Saidi, M. R. Org. Lett. 2006, 8, 2079. (b) Rasalkar, M. S.; Bhilare, S. V.; Deorukhkar, A. R.; Darvatkar, N. B.; Salunkhe, M. M. Can. J. Chem. 2007, 85, 77. (c) Wang, E.; Huang, T.-K.; Shi, L.; Li, B.-G.; Lu, X.-X. Synlett 2007, 2197.

10. Firouzabadi, H.; Iranpoor, N.; Jafari, A. A. J. Organomet. Chem. 2005, 690, 1556.

11. Azizi, N.; Saidi, M. R. Tetrahedron 2007, 63, 888.

12. Dias, A. S.; Lima, S.; Pillinger, M.; Valente, A. A. Carbohydr. Res. 2006, 341, 2946.

13. Kozhevnikov, I. V.; Sinnema, A.; Jansen, R. J. J.; Pamin, K.; Van Bekkum, H. Catal. Lett. 1995, 30, 241.

14. Moffat, J. B. In Metal-Oxygen Cluster - The Surface and Catalytic Properties of Heteropoly Oxometalates; Kluwer: New York, 2001; p 25.

15. Kozhevnikov, I. V.; Kloetstra, K. R.; Sinnema, A.; Zandbergen, H. W.; van Bekkum, H. J. Mol. Catal. A: Chem. 1996, 114, 287.

16. Rafiee, E.; Shahbazi, F. J. Mol. Catal. A: Chem. 2006, $250,57$.

17. Torviso, M. R.; Alesso, E. N.; Moltrasio, G. Y.; Vàzquez, P. G.; Pizzio, L. R.; Càceres, C.V.; Blanco, M. N. Appl. Catal. A 2006, 301,25 .

18. Rafiee, E.; Rashidzadeh, S.; Azad, A. J. Mol. Catal. A: Chem. 2006, 261, 49.

19. Zhang, F. M.; Wang, J.; Yuan, C. S.; Ren, X. Q. Catal. Lett. 2005, $102,171$.

20. Izumi, Y.; Hisano, K.; Hida, T. Appl. Catal. A 1999, 181, 277.

21. Casimir, J. R.; Turetta, C.; Ettouati, L.; Paris, J. Tetrahedron Lett. 1995, 36, 4797.

22. Godfrey, A. G.; Brooks, D. A.; Hay, L. A.; Peters, M.; McCarthy, J. R.; Mitchell, D. J. Org. Chem. 2003, 68, 2623.

23. Mukhopadhyay, M.; Bhatia, B.; Iqbal, J. Tetrahedron Lett. 1997, $38,1083$.

24. (a) Barluenga, J.; Viado, A. L.; Aguilar, E.; Fustero, S.; Olano, B. J. Org. Chem. 1993, 58, 5972. (b) Enders, D.; Moser, M.; Geibel, G.; Laufer, M. C. Synthesis 2004, 2040.

25. (a) Kobinata, K.; Uramoto, M.; Nishii, M.; Kusakabe, H.; Nakamura, G.; Isono, K. Agric. Biol. Chem. 1980, 44, 1709. (b) Daehn, U.; Hagenmaier, H.; Hoehne, H.; Koenig, W. A.; Wolf, G.; Zaehner, H. Arch. Microbiol. 1976, 107, 249. 
26. Tiwari, A. K.; Kumbhare, R. M.; Agawane, S. B.; Ali, A. Z.; Kumar, K. V. Bioorg. Med. Chem. Lett. 2008, 18, 4130.

27. Jeffs, P. W.; Redfearn, R.; Wolfram, J. J. Org. Chem. 1983, 48, 3861.

28. Dallemagne, P.; Rault, S.; Severicourt, M.; Hassan, K. M.; Robba, M. Tetrahedron Lett. 1986, 27, 2607.

29. Paleo, M. R.; Dominguez, D.; Castedo, L. Tetrahedron Lett. 1993, $34,2369$.

30. Dakin, H. D.; West, R. J. Biol. Chem. 1928, 78, 745.

31. Rao, I. N.; Prabhakaran, E. N.; Das, S. K.; Iqbal, J. J. Org. Chem. 2003, 68, 4079 and references therein.

32. Bahulayan, D.; Das, S. K.; Iqbal, J. J. Org. Chem. 2003, 68, 5735.

33. Nagarapu, L.; Bantu, R.; Puttireddy, R. Applied Catalysis A: General 2007, 332, 304.

34. Pandey, G.; Singh, R. P.; Garg, A.; Singh, V. K. Tetrahedron Lett. 2005, 46, 2137.

35. Khodaei, M. M.; Khosropour, A. R.; Fattahpour, P. Tetrahedron Lett. 2005, 46, 2105.

36. Das, B.; Krishnaiah, M.; Laxminarayana, K.; Reddy, K. R. J. Mol. Catal. A: Chemical. 2007, 270, 284.

37. Mirjafary, Z.; Saeidian, H.; Sadeghi, A.; Moghaddam, F. M. Catalysis Commun. 2008, 9, 299.

38. Rafiee, E.; Shahbazi, F.; Joshaghani, M.; Tork, F. J. Mol. Catal. A: Chemical. 2005, 242, 129.

39. (a) Heravia, M. M.; Ranjbar, L.; Derikvand, F.; Bamoharram, F. F. J. Mol. Catal. A: Chemical. 2007, 276, 226. (b) Mosaddegh, E.; Islami, M. R.; Hassankhani, A. Lett. Org. Chem. 2007, 4, 524.

40. Khan, A. T.; Choudhury, L. H.; Parvin, T.; Ali, M. A. Tetrahedron Lett. 2006, 47, 8137.
41. Selvam, N. P.; Perumal, P. T. Arkivoc 2009, 10, 265.

42. Yakaiah, T.; Lingaiah, B. P. V.; Reddy, G. V.; Narsaiah, B.; Rao, P. S. Arkivoc 2007, 13, 227.

43. Pandey, G.; Singh, R. P.; Grag, A.; Singh, V. K. Tetrahedron Lett. 2005, 46, 2137.

44. (a) Bhatia, B.; Reddy, M. M.; Iqbal, J. J. Chem. Res., Synop. 1994, 713. (b) Rao, I. N.; Prabhakaran, E. N.; Das, S. K.; Iqbal, J. J. Org. Chem. 2003, 68, 4079 .

45. Bahulayan, D.; Das, S. K.; Iqbal, J. J. Org. Chem. 2003, 68 , 5735.

46. (a) Eibracht, P.; Schimdt, A. Chem. Rev. 1999, 99, 3329. (b) Ugi, I. Pure Appl. Chem. 2001, 77, 187. (c) Bagley, M. C.; Cale, J. W.; Bower, J. Chem. Commun. 2002, 1682. (d) Bora, U.; Saikia, A.; Boruah, R. C. Org. Lett. 2003, 5, 435.

47. (a) Zhu, J.; Bienayme, H. In Multicomponent Reactions; Wiley: Weinheim, 2005. (b) Beck, B.; Hess, S.; Dömling, A. Bioorg. Med. Chem. Lett. 2000, 10, 1701.

48. (a) Nasr-Esfahani, M.; Montazerozohori, M.; Moghadam, M.; Mohammadpoor-Baltork, I.; Moradi, S. Phosph. Sulfur Silicon 2010, 185, 261. (b) Nasr-Esfahani, M.; Montazerozohori, M.; Moghadam, M.; Akhlaghi, P. Arkivoc 2010, 2, 97.

49. (a) Misono, M.; Misono, N.; Katamura, K.; Kasai, A.; Konishi, Y.; Sakata, K.; Okuhara, T.; Yoneda, Y. Bull. Chem. Soc. Jpn. 1982, 55, 400. (b) Chang, T. H. J. Chem. Soc., Faraday Trans. 1995, 91, 375. (c) Fournier, M.; Thouvenot, R.; Rocchiccioli-Deltcheff, C. J. Chem. Soc., Faraday Trans. 1991, 87, 349. (d) Yadav, G. D.; Kirthivasan, N. J. Chem. Soc., Faraday Trans. 1995, 91.

50. Bielánski, A.; Lubánska, A.; Pózniczek, J.; Micek-Ilnick, A. Applied Catalysis A 2003, 238, 239. 